\title{
Gothic Monstrosity: Charles Brockden Brown's Edgar Huntly and the Trope of the Bestial Indian
}

\section{Christine Yao}

In gothic fiction, monstrous acts committed by monstrous creatures mark spatial and symbolic frontiers: horror is generated not only when deviant acts such as cannibalism are carried out by bestial monsters on the fringes of society, but also these savage acts can collapse the conventional categories of the human and the monster. Within the framework of the American gothic, these integral tropes of cannibalism and bestial savagery - visible in works as diverse as Edgar Allan Poe's The Narrative of Arthur Gordon Pym (1838) and The Texas Chainsaw Massacre (1974) - can be traced back to the colonial legacy representing American Indians as animalistic and cannibalistic. ${ }^{1}$ The monsters that haunt the American gothic signal the return of the traumas of national history and the speaking of suppressed voices from the ongoing violence of America's colonial past. Jeffrey Jerome Cohen claims the figure of the monster is 'an embodiment of a certain cultural moment - of a time, a feeling, and a place', demanding analysis 'within the intricate matrix of relations (social, cultural, and literary-historical) that generate them' (Cohen 1996: 4, 5). In what follows, I focus on the development and sedimentation of the savage image of American Indians in early American history through the monstrous tropes of the American gothic, concluding this genealogy with Charles Brockden Brown's 1799 novel, Edgar Huntly. In his introduction to Edgar Huntly, Brown discusses the inspirational devices available to the American writer: 'Gothic castles and chimeras, are the materials usually employed for this end. The incidents of Indian hostility, and the perils of the western wilderness, are far more suitable; and, for a native to America to overlook these, would admit of no apology' (Brown 1988: 3). If for Brown, acclaimed as the pioneer of American gothic, the American setting equivalent to 'Gothic castles' are the 'perils of the western wilderness', Native Americans are the monstrous equivalent of the mythical chimera. With both the chimera and the Indian posited as inhuman and antagonistic Others, 
Brown positions the Indian as a quintessential element of the American gothic genre, and as both integral and liminal. Edgar Huntly participates in what Colleen E. Boyd and Coll Thrush call the 'Indian uncanny': a racialized formulation of Sigmund Freud's concept of the uncanny, which reveals the discomforting connections between the unfamiliar uncanny, 'das Unheimliche, or 'the unhomely', and the familiar 'das Heimliche, the homely' (Boyd and Thrush 2011: ix; Freud 2003: 134). The Indian uncanny exposes the disturbing tensions within familiar North American histories: it expresses 'the moral anxieties and uncertainties provoked by the dispossession of a place's Indigenous inhabitants', appropriates and misinterprets indigenous beliefs, and finally 'disrupt[s] dominant and official historical narratives as expressions of liminality', drawing attention to conflicts of production and power behind forms of knowledge (Boyd and Thrush 2011: ix).

The Indian uncanny in Edgar Huntly is not the ghostly presence of the deceased, but is the vital force of living individuals. Cohen notes that monsters do not just signal cultural limits, but also are 'a form suspended between forms that threatens to smash distinctions' (Cohen 1996: 6). In Brown's novel the colonialist figurations of bestiality and cannibalism become unmoored from their associations with Native Americans: the titular white protagonist descends into savagery not only through his violent acts against the Lenni-Lenape Indians, but also through the ironic reversal of these tropes, transforming Edgar into one of the monsters he fights against. My reading of Edgar Huntly brings together colonial histories, animal studies and indigenous philosophies in order to interrogate how the binary between the civilized and the savage is not a static either/or state: the twin monstrous tropes of difference indicate the paradoxical fear of underlying sameness and interdependence that would collapse fundamental boundaries between categories viewed as ontologically opposed. To Edgar Huntly, the interdependence of kinship - as that is viewed through an indigenous perspective - is a chimerical monstrosity, a perspective representative of the mindset of American settler colonialism. These kinships are chimerical in that they mix categories seen as different, and, like the mythical chimeras, are seen only as monstrous by a Western paradigm that denies shared associations between the colonizer and the colonized.

\section{Monstrous Histories, Monstrous Subjects}

The monsters that populate the American gothic owe their inhuman characteristics to a history of subjugation and dehumanization that goes 
back to Christopher Columbus's voyages. Two dominant tropes about indigenous savagery emerge from this ur-moment of colonialism in the New World, both predicated upon the threat they pose to the Western conceptions of civilization: the human as animal; and the human as cannibal. On Christopher Columbus's second voyage, Dr Diego Alvarez Chanca wrote a letter to the city of Seville, containing this observation of an indigenous village in the aftermath of a violent clash between the Spanish and Indians: 'These people are so like animals that they have not the intelligence to find a proper place to live' (Columbus 1969: 147). Dr Chanca meets this scene of violence with representational violence: denigrating Indians through a comparison to savage animals even as he imposes Western criteria for civilization. Although the idea of anthropophagy existed prior to Columbus's voyages, the term 'cannibal' was coined as result of his explorations: 'cannibal' is a corruption of 'Carib', part of Columbus's dubious distinction between the 'good' Arawak Indians and the 'bad' Caribs (Hulme 1986: 68). On his third voyage, Columbus details an exchange with some inhabitants who describe:

a land bordering on theirs, to the west, which was very high and not far away. But they all told me not to go there because the inhabitants ate men. I presumed from this that these inhabitants were Caribs like the other cannibals I had met. But I have thought since that they may have meant not cannibals but wild animals. (Columbus 1969: 215)

Here we can see not only the accusation of cannibalism as a shifting signifier of difference, but Columbus's self-serving confusion between the animal and the cannibal, demonstrating the twin nature of these dehumanizing tropes in the colonial project. Cannibalism and the bestial are similar insofar as both must be read as monstrous difference. Much as the savage person becomes the same as an animal, the alleged cannibal's diet also presumes this similarity, taking the human as meat indistinguishable from the animal. By his fourth voyage, Columbus has become such an expert on eaters of flesh that he is able to objectify indigenous peoples based on appearance alone: 'I found other tribes who ate human flesh, as their brutal appearance showed' (Columbus 1969: 298). The founding moment of colonization in the Americas both constructed and naturalized the twin monstrous tropes used to represent indigenous peoples, thereby legitimizing the moral authority to conquer and colonize.

Turning from the first moment of Spanish colonialism in America to the first moments of colonialism in seventeenth-century New England, these monstrous tropes still haunt the American wilderness in the 
writings of William Bradford, governor of Plymouth Colony, and John Winthrop, governor of Massachusetts Bay Colony. ${ }^{2}$ Upon arriving in America via Cape Cod on 6 September 1620, Bradford comments on the predicament of the colonists: there are 'these savage barbarians [who were] readier to fill their sides full of arrows than otherwise', and the landscape was 'a hideous and desolate wilderness, fall [sic] of wild beasts and wild men' (Bradford 1952: 62). Similarly, in Winthrop's entry for 5 October 1642, he muses on unrest in the colony:

For such as come together into a wilderness, where are nothing but wild beasts and beastlike men, and there confederate together in civil and church estate, whereby they do, implicitly at least, bind themselves to support each other, and all of them that society, whether civil or sacred, whereof they are members. (Winthrop 1996: 416)

Both Bradford and Winthrop equate Native Americans with wild animals through parallelisms, thereby justifying violence against these monstrous Indians and the establishment of the Puritan colonies as bastions of civilization and order in the paradoxically populated yet empty wilderness.

As in Columbus's diaries, cannibalism appears in early American documents in order to characterize Native Americans as bestial savages, thereby justifying colonization and the dispossession of Indian land. Mourt's Relation, believed to be written primarily by Edward Winslow with some contributions from William Bradford, depicts the events following the landing of the Mayflower and the establishment of Plymouth Colony. Published in 1622, in contrast to Bradford's manuscript Of Plymouth Plantation which was only published in 1856, Mourt's Relation was meant to act as 'a promotional effort' in order to encourage new settlers to come to the colony (Mourt's 1963: xv). The association between the Indians and cannibalism, therefore, serves as a crucial example of how allegations of cannibalism worked as propaganda within the colonialist context. ${ }^{3}$ In November 1620, the settlers went on an expedition and discovered burial grounds: despite deciding to leave the first graves in peace 'because we thought it would be odious unto them to ransack their sepulchres', upon finding the second burial grounds, the colonists decide to go against their earlier attitude of respect and exhume the contents (Mourt's 1963: 21). Engaging in proto-anthropological work, they speculate about the contents of the grave and its corpse, observing that the skull had 'some of the flesh unconsumed' (Mourt's 1963: 27). The implication becomes that the Indians were cannibals, giving the settlers a moral authority to colonize and civilize the land. Even the more liberal Roger Williams, who was an advocate for more equable interactions 
with Indians, records hearsay about cannibals throughout A Key Into the Language of America. According to Williams, mohowaúgsuck is Narragansett for 'The Canibals, or, Men-eaters, up into the west, two, three or foure hundred miles from us' and cummóhucquock translates as 'They will eate you' (Williams 1997: 16). The idea of savage Indians endures, haunting the popular early American genre of the captivity narrative and justifying the violence of the Indian wars. 'Cannibal' still acts as the horizon of civilized humanity, a marker of difference that transforms Indians into the originary monsters of American gothic fiction.

The conflict between colonists and Native Americans plays out on the ideological front, demonstrating the incommensurability of settler and indigenous paradigms when it comes to the place of humans among other living beings. Gregory Cajete emphasizes that Native American thought does not make the same distinctions between the human and the animal as Western epistemologies do, due to the mutual and fluid interrelation of the worlds of the human, the spiritual, and the animal: not only are animals seen as having souls, but the distinct category of 'animal' does not exist in most Native languages (Cajete 2000: 152). While specific names exist for specific animal species, the general category of 'animal' cannot be abstracted for, as Cajete stresses, the Native view of animals cannot be divorced from the animals' roles in their respective environmental, useful and symbolic contexts (150). In contrast, Western thought is dependent upon the animal/human binary that comes out of the opposition between nature and culture which, as Eric Cheyfitz points out, is 'a model the West has exported imperially with increasing force since 1492' (Cheyfitz 2009: 143). According to Colleen Boggs, animality is used to create 'a position of nonsubjectivity and of socially sanctioned abjection', which she traces through American history from the Puritan bestiality trials to Abu Ghraib (Boggs 2010: 99). The Native American relationship with animals clashes with the Western abjection of animals; indeed, early American history is the site of the further reification of the Western animal/human binary, with the colonizers violently treating Native Americans like abjected animals, unable to comprehend the Native perspective that would allow for more complex relationships between living beings.

Derrida's work on animality further explains the logic on which the animal/human boundary is dependent, positioning it as part of the creation and maintenance of social power. In order to think through the Western paradigm, Derrida analyses the figures of the beast and the sovereign: the first, not exactly the animal but rather the bestial; the second 'a sovereignty that is most often represented as human or divine, in truth anthropo-theological' (Derrida 2009: 14). If the dualism of the beast 
and the sovereign are seen in a relation of opposition, then the beast acts as the subordinated state in the obverse of the power of the sovereign. Both are what Derrida calls 'situated by definition at a distance from or above the laws, in nonrespect for the absolute law, the absolute law that they make or that they are but they do not have to respect' (Derrida 2009: 17). Within this scheme they are diametrically opposed, because animality is 'the place where the law does not appear, or is not respected or gets violated', while the sovereign subject is 'the form of the Law itself, of the origins of laws, the guarantor of laws' (Derrida 2009: 17). Thus, the animal, the place of abjection and violation, is a constitutive part of the fundamental structure required for the production of the power of sovereignty and the law. ${ }^{4}$ In other words, 'civilization' can only exist in relation to its opposite, the 'frontier'. By deploying the trope of bestial non-human identity, the colonizers of the New World add a weapon to the arsenal of colonialist tactics that abjects the Indians outside of the law into the bestial state even as the colonizers authenticate their sovereign power as the makers of law. This strategy is the power of naming: as Derrida says, 'Animal is a word that men have given themselves the right to give' (Derrida 2008: 32). The dehumanization of such groups as Native Americans through animalistic representations persists because of, and to further relationships to, institutions of power. The creation of monsters that bridge the categories of animal and human is an ideological necessity.

American gothic fiction draws upon these tropes in order to exploit their horror and explore the tensions around these 'monsters' and the power relationships they represent and reinforce. The terror in American gothic fiction often comes from questioning exactly who the monsters truly are, reflecting the complexity of historical ambiguities that in turn complicate the attempts to maintain the strict divisions required by ideology. Even as the Puritans imagined on their physical and symbolic frontiers the threat of animalistic and cannibalistic Indians, the decoupling of 'cannibal' from a definitive racial category meant the horrifying realization that the settlers, too, could be cannibals. For the New England colonists, the Starving Time tragedy in Jamestown earlier in the seventeenth century provided evidence for cannibalism emerging amongst the settlers themselves. The Starving Time occurred as a result of the Powhatan Confederacy's attempt to force the colonists from Virginia by isolating them from food supplies; combined with a poor growing season, only sixty people were left alive (Edmund S. Morgan, cited in Herrmann 2011: 47). The disturbing implication for colonists was that the Indians, those seen as bestial and possibly cannibalistic, could create conditions for Americans to become cannibals themselves, completely reversing the use of cannibalism in discourses of Othering. 
Maggie Kilgour posits that 'cannibalism involves both the establishing of absolute difference, the opposite of eater and eaten, the dissolution of that difference, through the act of incorporation which identifies them, and makes the two one' (Kilgour 1998: 240). Thus, the myth of cannibalism is 'now explicitly revealed to be a story about ourselves, not others, as the cannibal has moved from the fringes of our world to its very centre' (247). Both eater and eaten are recognized as meat, collapsing the distinction between animal and human. In his essay ' $O f$ Cannibals', influential early modern writer Montaigne declares: 'I think there is nothing barbarous and savage in this nation [America], from what I have been told, except that each man calls barbarism whatever is not his own practice' (Montaigne 1943: 77). Idealizing Indian society as pure and primitive, Montaigne paints the act of cannibalism as one of community and unity: prisoners are treated 'with all the hospitality they can think of' and once killed, 'they roast him and eat him in common and send some pieces to their absent friends' (Montaigne 1943: 84). While Montaigne does judge this act as 'barbarous horror', he reverses the expectations of savage and civilized, calling Western tortures and executions barbarous and decries them as worse than cannibalism: 'I am heartily sorry that, judging their faults rightly, we should be so blind to our own' (85). Eric Cheyfitz comments that Montaigne's depiction of cannibalism demonstrates 'the basis of most Native American civilization: kinship. Cannibalism expresses, or figures forth, a radical idea of kinship that cuts across frontiers of hostile groups' (Cheyfitz 1991: 149); the act signifies the composite constitution of the self and Other as well as the kinship economy which is composed of interconnectivity between all things on a foundation of 'the essentially equivocal' (Cheyfitz 1991: 149). ${ }^{5}$ Returning to genre, Eric Savoy proposes a theory for the American gothic: because the past cannot be forgotten or repressed, the genre attempts to resurrect the 'specter of Otherness that haunts the house of national narrative', but cannot entirely explain or speak to these traumas (Savoy 1998: 14). For the genre of the American gothic, Jamestown's status as a foundational story for colonialism in America opens one of many possibilities for the collapse of whiteness into the tropes of savagery tied to Native Americans positioned at the heart of the national project.

\section{Edgar Huntly's Colonial Haunting}

Ever since Jared Gardner's foundational discussion of the representation of race in Edgar Huntly, scholars have understood the novel's portrayal 
of Native Americans as political, not merely psychological. Building on this conclusion, it can be argued that the tropes that characterize the monstrosities of the American gothic draw upon the power of the sedimented history of the representations of Native American; the horror of these monstrosities resonates with the fundamental divide between the civilized and the savage in the Western paradigm. But often the true horror of these gothic tales - from Edgar Allan Poe to Stephen King arises when the fragility of this problematic binary collapses, exposing the true monsters among the so-called civilized and opening the possibility of monsters that lurk in the hearts of all. Given American gothic's obsession with the past, I look to the genre's own past by reading the monsters of Charles Brockden Brown's Edgar Huntly, the first American gothic novel, in light of the genealogy of colonialist tropes about Native Americans outlined above.

Set in 1787, Edgar Huntly's protagonist goes on a quest for justice after the sudden murder of his friend Waldegrave, but finds himself entangled in both the uncertain inheritances of his friend's other dealings and the alleged crimes of the servant, Clithero Edny. Edgar finds himself fascinated by Clithero's past and soon he inexplicably adopts Clithero's habit of sleepwalking, sharing his friend's predilection for morose wanderings in the apparently empty wilderness, which serves as a sympathetic background. The second half of the narrative abruptly transitions with Edgar awakening in a dark cave with a panther as his companion, and as an eventual meal, before he discovers that the wilderness is not so empty after all: he engages in the brutal slaughter of LenniLenape Indians as he attempts to make his way back to civilization in the midst of an apparent war over the unlawful seizure of Indian land. The strange resolution of one of these disparate narrative threads reveals that Waldegrave's murderer was one of the Indians, an epiphany sometimes questioned by critics.

The dangerous instability of race and identity in Edgar Huntly has been a topic of scholarly discussion from Gardner's argument about the influence of debates around the Alien and Sedition Acts to Katy Chiles's exploration of Brown's engagement with the mutability of race in eighteenth-century natural history. Amidst these important investigations into historical context, I call for attention to the symbolic valences of Brown's rhetorical figuration of Native Americans in his manifesto about the American gothic. To return to Brown's introduction, hostile Indians populate the perilous western wilderness as the equivalent of chimeras in gothic castles. By identifying Indians with the chimera, Brown does not merely cast Native Americans as monstrous; he specifically describes them as chimerical. The fantastical chimera, as an 
amalgamation of different beasts, undermines naturalized and essentialized identity. ${ }^{6}$ Colonial tropes of Native American monstrosity share with the chimera the characteristics of both collapsing differences and fundamental sameness; both the figures of the animalistic and the cannibalistic Indians suggest the chimerical, insofar as they describe organic links between categories seen as mutually exclusive within the normative Western paradigm. The Indian as chimera becomes a threat to cohesive white American identity: the chimera suggests the constitutive interrelationship not only between Native Americans and white Americans, but also between human and animal, an organic kinship that we have seen the binary Euro-American paradigm fundamentally denies. From the normative American perspective, to be chimerical is to be monstrous, and vice versa.

The use of the word 'chimerical' in Edgar Huntly gestures toward this dilemma. Appearing only during Clithero's narration of his complicated past, 'chimerical' is associated not just with confusion, but also with such feelings as love and sympathy: the villainous Arthur Wiatte views love and friendship as 'chimerical' delusions that can 'in people of sense, be rectified by experience' (Brown 1988: 44); Clithero must act on his love or else remain in what he calls a 'chimerical project' of lovesickness (Brown 1988: 49); love beyond a certain age is called 'chimerical and marriage folly' (Brown 1988: 58); and Clithero justifies his attempt to murder his benefactress Mrs Lorimer because he accidentally killed her twin, Arthur, reasoning that 'the force of sympathy might be chimerical', and so he may as well save her from emotional devastation by performing a mercy killing (Brown 1988: 74). Love and sympathy are labelled as chimerical feelings: they are viewed by these characters as foolish, or even worse, dangerous. Seen as feelings that should be overcome, Arthur's and Clithero's actions to suppress these chimeras paradoxically lead to behaviours and actions that cause the men to be viewed as monstrous.

Significantly, Clithero's narration, which dominates the first half of the novel, takes place in Ireland - the site of the castles and chimeras that Brown identifies as the main tropes of the European gothic tradition. When the narrative returns to Edgar in Norwalk, Pennsylvania, the American gothic equivalent of the chimerical monsters are revealed. In the second half of Brown's novel, Edgar sleepwalks himself into a dark cave where his confrontation with the panther is closely followed by his clash with the local Lenni-Lenape Indians; he faces his chimeras, discovering that he, too, is monstrous. To Edgar, the panther possesses a 'grim and terrific visage' when it is hunting him; later, Edgar describes the 'tawny and terrific visage' of one of the Lenni-Lenape Indians just 
before he shoots him (Brown 1988: 120, 183). Here, he continues the tradition, outlined earlier, of dehumanizing Indians by equating them to savage animals. What is provocative, however, is that he does not just make the Indians into beast-like men, but makes the panther into a man-like beast: before this sleepwalking incident and during his search for Clithero, he is struck by a panther's cry's 'resemblance to the human voice' - that is, its similarity to the category of human in general, not just the Indian 'savages' (Brown 1988: 118). The panther falls into a dark pit, giving Edgar a temporary reprieve. But his victory is short: this blurring of categories sets up Edgar's complete collapse into chimerical confusion when he awakens from his sleepwalking in possibly the same dark pit with what is possibly the panther, having literally descended to the feline's level. Edgar unwittingly enacts what Aimé Césaire calls the dehumanizing paradox of colonization: 'the colonizer, who in order to ease his conscience gets into the habit of seeing the other man as an animal, accustoms himself to treating him like an animal, and tends objectively to transform himself into an animal' (Césaire 1972: 31).

Much has been made of the fact that Edgar's brutal and unprovoked massacre of five Indians makes him the same savage monster as those Indians who had massacred his family in the past: Richard Slotkin declares that Edgar 'has become the thing he hunts'; Robert D. Newman claims 'the underlying irony of the novel is the revelation of the savage potential of the white man'; and many critics note that Edgar uses a tomahawk and resorts to the kind of trickery that was represented as stereotypical of Native Americans (Slotkin 1973: 389; Newman 1988: 68; Christophersen 1993: 135). Yet what I want to analyse with greater precision is the fact that Edgar's fall into savagery with the panther is signalled by the same chimerical signifiers he associates with the Indians. In the pit, the ravenous Edgar admits he 'felt a strong propensity to bite the flesh from my arm. My heart overflowed with cruelty, and I pondered on the delight I should experience in rending some living animal to pieces, and drinking its blood and grinding its quivering fibres between my teeth' (Brown 1988: 157). The image of his potential selfcannibalization not only links him to the racist heritage of the native-ascannibal, but also allegorizes his self-destructiveness and the dissolution of difference. Indeed, shortly after this admission he kills and consumes the panther: 'I review this scene with loathing and horror', he claims, both admitting to the monstrous aspect of his actions while attempting to rationalize them, 'If this appetite has sometimes subdued the sentiments of nature and compelled the mother to feed upon the flesh of her offspring, it will not excite amazement that I did not turn from the yet warm blood and reeking fibres of a brute' (Brown 1988: 160). The 
ambiguity of 'brute', given Edgar's obsessive use of 'savage' to describe both animals and Indians, blurs human and animal differences.

In his analysis of this much-read passage, John Carlos Rowe comments that numerous critics have discussed how "the term "savage" effectively links the other terms in some sort of metonymic chain: Indian, panther, Clithero, are all predicates of the inchoate "savagery" (Rowe 2000: 46). This chain, I suggest, acts as a reminder of the erasure of differences akin to the autophagic cycle: Edgar's eating of the panther, after the slippages between animal, Indian and his subjectivity as a white American, is tantamount to cannibalism. During the sequence in which he hunts and kills the party of Indians, his chimerical confusion extends to his ability to discern differences between these categories. Cautiously looking for enemies, he first sees 'movements which appeared like those of a beast' akin to 'a wolf, or panther, or bear' but realizes it is 'an human adversary' (Brown 1988: 191). For Edgar, the behavioural codes necessary for recognizing animal and savage Indian overlap, as he observes that the man 'moved upon all fours, and presently came near enough to be distinguished. His disfigured limbs, pendants from his ears and nose, and his shorn locks, were indubitable indications of a savage' (Brown 1988: 191). After this stream of shifting observational uncertainty, he retroactively claims that he was 'at no loss to interpret these appearances' in order to rationalize his ambush and slaughter of the lone surviving Indian (Brown 1988: 191).

When Edgar begins to return to civilization, he calls upon his reserves of strength and stamina, declaring:

I disdained to be out-done in perspicacity by the lynx, in his sure-footed instinct by the roe, or in patience under hardship, and contention with fatigue, by the Mohawk. I have ever aspired to transcend the rest of animals in all that is common to the rational and brute, as well as in all by which they are distinguished from each other. (Brown 1988: 203)

Thus, the contradiction within his efforts to transcend the overlapping categories of the animal and the Indian is revealed: he must adopt the traits he assigns to these degraded entities. Edgar has reached the point of being able to decouple racial signifiers from their supposed essences: later, he even accidentally attacks a force of villagers from Solebury looking for him, mistaking the white Americans for the Lenni-Lenape Indians. With the same unquestioning certainty as in his previous interpretations, he reads the villagers as Indians since they were walking in a straight line 'peculiar to the Indians' (Brown 1988: 211). Edgar's chimerical perspective allows him to see the kinship between living beings; however, he cannot fully embrace this radical divergence from 
the Western paradigm and therefore must see the chimerical as monstrous. As a consequence, he repeatedly seeks to destroy that which was the monstrous other now uncannily like his own self.

\section{Narrative Monstrosity and American Gothic}

But what of the savage monstrosity of American gothic, writ large? I want to suggest that Brown uses Edgar Huntly not only to establish the essential monstrous tropes of the American gothic and their connection to Native Americans, but also to present the importance of remembering this linkage between narrative trope and ongoing historical reality. In his 1803 pamphlet An Address to the Government of the United States on the Cession of Louisiana, Brown ventriloquizes the voice of a fictive French councillor in order to steer public and government opinion toward seizing Louisiana; through this device, Brown also levies critiques against the hypocritical foundations of America: 'Devoted to the worst miseries is that nation which harbours in its bosom a foreign race, brought, by fraud and rapine, from their native lands who are bereaved of all the blessings of humanity' (Brown 1803: 73). This French persona views the horrors of slavery as intertwined with the colonial history of Native American conflicts:

The only aliens and enemies within [America's] borders, are not the blacks. They are indeed the most inveterate in their enmity; but the Indians are, in many respects, more dangerous inmates. Their savage ignorance, their undisciplined passions, their restless and war-like habits, their notions of ancient right, make them the fittest tools imaginable for disturbing the states. (Brown 1803: 74)

Even as Brown ostensibly writes this pamphlet with an eye to the future of America, he acknowledges that the past cannot be suppressed, creating fault lines that weaken the nation.

The accuracy and complexity of Brown's portrayal of this Native American past has been questioned and sometimes seen as indicative of flaws in the design of the narrative. Sydney J. Krause draws attention to treaties and land frauds in Pennsylvania that resulted in seemingly deserted areas such as the novel's Norwalk, going back to William Penn's agreement with the Lenni-Lenape or Delaware Indians and the subsequent abuse of the Walking Purchase Treaty. Norwalk as a setting is a place "where the past hangs heavy, where its energies, its angers, its terrors from "about thirty years ago" still haunt', claims Kafer (Kafer 2004: 176). Some of the various ways Edgar Huntly's Indians have been 
read include Indians as 'phantoms of the mind', 'phantoms of the culture', 'and as Lenni-Lenapes living in late-eighteenth-century Pennsylvania' (Christophersen 1993: 156). According to Christophersen, even with the novel's awareness of Indian victimization, their narrative status as 'boogeymen of the wilderness' means that 'even the Indian's identity as an exploited population interests Brown only as it illuminates white America' (Christophersen 1993: 156). Criticisms about Brown's use of Native Americans pairs with dissatisfactions over the novel's structure: Fiedler dismisses the Native American component of the conclusion as 'irrelevant to what has become the real theme of the book', calling the novel 'a charmingly, a maddeningly disorganized book', an accusation which has plagued the novel ever since (Fiedler 1960: 144). At the beginning of the novel Edgar admits to his fiancée Mary Waldegrave the difficulty he has in putting together a wholly coherent narrative: 'That the incidents I am going to relate can be recalled and arranged without indistinctness and confusion? That emotions will not be re-awakened by my narrative, incompatible with order and coherence?' (Brown 1988: 5). By pairing Edgar Huntly's representation of Native Americans with the strange and sometimes frustrating unveiling of the narrative, I argue that we can see how the novel is structured on the belated unveiling of both Indian presences and history.

The first half of the narrative is bereft of Indian presences - indeed, Clithero and Edgar wander the wilderness of Norwalk as if it were an abandoned gothic castle. Clithero is drawn to Norwalk during his guiltridden sleepwalking, which acts as the site of Clithero's confession to Edgar; the caves and crags of Norwalk are the backdrop of pathetic fallacy to the emotional confusion and psychological drama of the characters. Throughout the first part of the novel, Edgar relates his intimate knowledge of Norwalk's flora and fauna as well as the limestone composition of its geography that makes the region prone to caves: 'Perhaps no one was more acquainted with this wilderness than I' (Brown 1988: 92). But his knowledge and enjoyment of Norwalk as a place is predicated upon the wilderness as empty. He declares, 'I love to immerse myself in shades and dells, and hold converse with the solemnities and secrecies of nature in the rude retreats of Norwalk' and presumes that Clithero is likewise drawn to its 'charms of solitude, of a lonely abode in the midst of mountainous and rugged nature' (Brown 1988: 90, 91). As he explores the wilderness, Edgar muses that:

It was probably that human feet had never before gained this recess, that human eyes had never been fixed upon these gushing waters. The aboriginal inhabitants had no motives to lead them into caves like these ... Since 
the birth of this continent, I was probably the first who had deviated thus remotely from the customary paths of men. (Brown 1988: 99)

Edgar echoes William Bradford's and John Winthrop's assumptions about the land as terra nullius, invoking the history of American colonialism.

Edgar only remembers that his beloved Norwalk is populated by the Lenni-Lenape Indians in the latter half of the novel. When he stumbles across the Indian camp he suddenly recalls the Indian wars as they pertained to that part of Pennsylvania. Disoriented upon seeing the sleeping figures and concluding that they are Indians, he wonders, 'Had some mysterious power snatched me from the earth, and cast me, in a moment into the heart of the wilderness? Was I still in the vicinity of my paternal habitation or was I thousands of miles distant?' (Brown 1988: 164). Although Edgar somehow considers the presence of Indians mutually exclusive from the area he knows, he quickly realizes he is still in Norwalk and claims, 'I need not tell thee that Norwalk is the termination of a sterile and narrow tract, which begins in Indian country' (Brown 1988: 165). Despite his earlier ignorance, he recounts the history of the Indian wars from 'a long course of injuries and encouragements [that] had exasperated the Indian tribes; that an implacable and exterminating war was generally expected' to 'a band of them [who] had once penetrated into Norwalk, and lingered long enough to pillage and murder some of the neighbouring inhabitants' (Brown 1988: 166). This incident is burned into his memory, claims Edgar, because his parents and a baby sibling were murdered: 'You will not be surprized that the fate of my parents, and the sight of the body of one of this savage band, who, in pursuit that was made after them, was overtaken and killed, should produce lasting and terrific images in my fancy' (Brown 1988: 166). He rationalizes his slaughter of these Indians through this epiphany about the massacre of his parents, which he claims has so traumatized and formed him - a decidedly unsatisfying revelation given there was no indication of this apparently haunting personal past in the previous half of the novel.

The conclusion of Edgar Huntly continues belatedly to reveal the hitherto invisible centrality of the Lenni-Lenape Indians to both Norwalk and to Edgar's own narrative. Critics such as Matthew Sivils and Janie Hinds agree that the novel hinges on the under-examined figure of a Lenni-Lenape woman known as Old Deb. As Edgar makes his way back to Solebury, she is introduced when he goes to her hut; in a parallel to the seemingly abandoned wilderness of Norwalk, Old Deb is absent from her hut when Edgar seeks shelter there. During his home invasion Edgar 
gives an extensive account of her personal history and a surprisingly sympathetic history of the dispossession of Indian land. A matriarch of the Lenni-Lenape Indians, she alone remained on the land as a gesture of sovereignty when the rest of her tribe emigrated due to colonist expansion. In her eyes, the 'English were aliens and sojourners, who occupied the land merely by her connivance and permission, and whom she allowed to remain on no terms but those of supplying her wants' (Brown 1988: 199). Old Deb reigns with her three wolf-like dogs; tellingly in the context of Indians as beasts, we are told 'These animals differed in nothing from their kinsmen of the forest, but in their attachment and obedience to their mistress' (Brown 1988: 198). With Indians as 'their kinsmen of the forest', the dogs and the Lenni-Lenape are presented in the context of indigenous kinship. Hinds attends to the anthropomorphic language used to describe Deb's dogs, arguing that 'Deb is, in short, multiply hybrid: she is part of her tribe and she is related to the story's animals inasmuch as Edgar entangles the entire tribe's sensory attributes with those of predatory creatures' (Hinds 2004: 337). Given Edgar's earlier investment in the image of the savage and bestial Indian, it is a revelation to discover that Edgar and Old Deb have a pre-existing friendship of sorts: visiting one another on a frequent basis, 'she seemed to contract an affection for [him]' and he took 'some pains to study her jargon, and could make out to discourse with her' (Brown 1988: 200). Sivils reads these interactions as part of her battle for tribal sovereignty, retaining her presence on the land as well as the survival of her culture with Edgar 'unwittingly help[ing] preserve the culture whites are destroying' (Sivils 2001: 302). Edgar's life is intertwined with the previously maligned and disavowed Indians through his relationship to Old Deb, the chimerical Indian who introduces Edgar to indigenous ways long before his violent turn with the panther.

The wilderness of Norwalk has come to the town of Solebury: upon his return Edgar finds himself in the middle of a conflict between the Lenni-Lenape Indians and the townspeople. Deb herself emerges near the novel's end as a defiant member of this quickly suppressed uprising: 'She was not to be awed or intimidated by the treatment she received, but readily confessed and glorified in the mischief she had done; and accounted for it by enumerating the injuries which she had received from her neighbours' (Brown 1988: 270). It is Deb who has the knowledge and authority to give a straightforward chronology of the novel's events and actions from the Indian perspective, including the solution to the mystery of Waldegrave's death: during the preparations for the invasion, one of the Lenni-Lenape had entered Solebury with the intent to murder and had found the hapless Waldegrave as his victim (Brown 
1988: 271). Fiedler, among others, voices the complaint that this revelation about Waldegrave 'when it comes seems utterly anticlimactic', and the general dissatisfaction with the integration of the Indians into the novel (Fiedler 1960: 144). But what we see with Old Deb is the fundamental role of Native American resistance to the novel's underlying narrative; indeed, Edgar Huntly's gothic plot cannot be understood without its American chimeras.

In Brown's Edgar Huntly the tropes of gothic monstrosity and their monstrous effects are felt and shown before the Indians themselves appear. While Indians are cast as the American chimeras, the interlinking kinship that constitutes the chimerical extends to all living beings, despite its disavowal by the Western paradigm. History cannot be completely repressed: the tropes of colonization of the New World used to justify violence against Native Americans come back to haunt Edgar with a vengeance in order to try to make him face his own chimerical nature, which he cannot help but reject as monstrous. According to Savoy, in the genre of the American gothic, prosopopoeia is the primary device of the allegorical turn, allowing for the traumatic return of the bloody history of America and for the ghosts of the past to speak (Savoy 1998: 14). In Brown's novel, however, Old Deb is able to speak on behalf of herself and her people; the Indian uncanny reminds us that the history of American Indians is not dead and long past, for despite their seeming absence, they are shown to be very much present and alive. Through the narrative deferral of the appearance of Indians, the structure of Brown's novel allegorizes the relationship between the American gothic's monstrous tropes and the history and ongoing presence of Native Americans. Edgar Huntly suggests that when it comes to monstrous tropes in the American gothic, Native Americans may seem to be absent but their presences and history will eventually be revealed, demonstrating their continual survival and resistance.

\section{Notes}

Thanks to Eric Cheyfitz, Shirley Samuels and my peers at the English Department Roundtable for their thoughtful comments and feedback on this essay as it developed. An earlier version of this essay was presented at The Society of Early Americanists Eighth Biennial Conference.

1. In his landmark Love and Death in the American Novel, critic Leslie Fiedler articulates the origins of the American gothic genre in the 'certain special guilts' resulting from the 'dream of innocence [that] had sent Europeans across the ocean to build a new society immune to the compounded evil from the past from which no one in Europe could ever feel himself free', but which led to 'the slaughter of the Indians, who would not yield their lands to the 
carriers of utopia' (Fiedler 1960: 127). Fiedler highlights Charles Brockden Brown as the progenitor of the genre.

2. In his foundational work on the American myth of regeneration through violence, frontier clashes between colonists and Native Americans are the source of what Richard Slotkin calls 'the structuring metaphor of the American experience' (Slotkin 1973: 5).

3. Indeed, in The Man-Eating Myth, William Arens questions the existence of cannibalism among indigenous peoples due to the specious and biased nature of historical records and implicates his anthropological discipline in the perpetration of the myth. He lists some of the ways in which the accusation of cannibalism can be deployed: attributed to other groups in order to delineate between civilization and barbarism; used as a temporal marker 'in the progress of [one's] own cultural development' that relies on notions of primitivism; and wielded against current members within one's own group 'to explain the existence of constant evil and misfortune' (Arens 1979: 159).

4. One might want to compare Derrida's ideas about the beast and the sovereign to Giorgio Agamben's concepts about bare life and sovereign power in Homo Sacer.

5. While cannibalism in this sense is a distortion of the Native concept of kinship, Jeff Berglund explores how contemporary Native American authors such as Leslie Marmon Silko and Sherman Alexie reappropriate the discourse of cannibalism in their work (Bergland 2006).

6. In Donna Haraway's iconic essay 'A Cyborg Manifesto' she fleetingly uses the term 'chimera' almost as a synonym for her concept of the 'cyborg': 'By the late twentieth century, our time, a mythic time, we are all chimeras, theorized and fabricated hybrids of machine and organism; in short, we are cyborgs' (Haraway 1991: 150). Unlike the cyborg, the chimera (while also a hybrid) is an organic assemblage of different elements and, one might say, a less voluntaristic model of interconnectedness; also, 'chimera' is a term more temporally relevant to an early America bereft of the particularly modern technologies identified by Haraway.

\section{References}

Arens, William (1979), The Man-Eating Myth, New York: Oxford University Press.

Berglund, Jeff (2006), Cannibal Fictions: American Explorations of Colonialism, Race, Gender, and Sexuality, Madison: University of Wisconsin Press.

Boggs, Colleen Glenney (2010), 'American Bestiality: Sex, Animals, and the Construction of Subjectivity', Cultural Critique, 76, 99-125.

Boyd, Colleen E. and Coll Thrush (2011), 'Bringing Ghosts to Ground', Phantom Past, Indigenous Presence, ed. Colleen E. Boyd and Coll Thrush, Lincoln: University of Nebraska Press, vii-xl.

Bradford, William [1856] (1952), Of Plymouth Plantation 1620-1647, ed. Samuel Eliot Morison, New York: Knopf.

Brown, Charles Brockden (1803), An Address to the Government of the United States on the Cession of Louisiana to the French and on the Late Breach of Treaty by the Spaniards, Philadelphia: John Conrad \& Co. 
Brown, Charles Brockden [1799] (1988), Edgar Huntly; or Memoirs of a SleepWalker, ed. Norman S. Grabo, New York: Penguin Books.

Cajete, Gregory (2000), Native Science: Natural Laws of Interdependence, Santa Fe: Clear Light Publishers.

Césaire, Aimé (1972), Discourse on Colonialism, trans. Joan Pinkham, New York: Monthly Review Press.

Cheyfitz, Eric (1991), The Poetics of Imperialism, New York: Oxford University Press.

Cheyfitz, Eric (2009), 'Balancing the Earth: Native American Philosophies and the Environmental Crisis', Arizona Quarterly, 65.3: 139-62.

Chiles, Katy L. (2014), Transformable Race: Surprising Metamorphoses in the Literature of Early America, Oxford: Oxford University Press.

Christophersen, Bill (1993), The Apparition in the Glass: Charles Brockden Brown's American Gothic, Athens, GA: University of Georgia Press.

Cohen, Jeffrey Jerome (1996), 'Monster Culture (Seven Theses)', Monster Theory, ed. Jeffrey Jerome Cohen, Minneapolis: University of Minnesota Press, 3-25.

Columbus, Christopher (1969), The Four Voyages, trans. J. M. Cohen, New York: Penguin Books.

Derrida, Jacques (2008), The Animal That Therefore I Am, trans. David Willis, ed. Marie-Louise Mallet, New York: Fordham University Press.

Derrida, Jacques (2009), The Beast and the Sovereign, trans. Geoffrey Bennington, ed. Michel Lisse, Marie-Luise Mallet and Ginette Michaud, Chicago: University of Chicago Press.

Fiedler, Leslie (1960), Love and Death in the American Novel, New York: Criterion Books.

Freud, Sigmund (2003), The Uncanny, trans. David Mclintock, London: Penguin Books.

Gardner, Jared (1994), 'Alien Nation: Edgar Huntly's Savage Awakening', American Literature, 66.3: 429-61.

Haraway, Donna Jeanne (1991), Simians, Cyborgs, and Women, New York: Routledge.

Herrmann, Rachel B (2011), 'The "tragicall historie": Cannibalism and Abundance in Colonial Jamestown', William and Mary Quarterly, 68.1: 47-74.

Hinds, Janie (2004), 'Deb's Dogs: Animals, Indians, and Postcolonial Desire in Charles Brockden Brown's Edgar Huntly', Early American Literature, 39.2: 323-54.

Hulme, Peter (1986), Colonial Encounters, London: Methuen.

Kafer, Peter (2004), Charles Brockden Brown's Revolution and the Birth of American Gothic, Philadelphia: University of Pennsylvania Press.

Kilgour, Maggie (1998), 'The Function of Cannibalism at the Present Time', in Cannibalism and the Colonial World, ed. Francis Barker, Peter Hulme and Margaret Iversen, New York: Cambridge University Press, 238-59.

Krause, Sydney J. (1994), 'Penn's Elm and Edgar Huntly: Dark "Instruction to the Heart"', American Literature, 66.3: 463-84.

Montaigne, Michel de (1943), Selected Essays, trans. Donald M. Frame, New York: Walter J Black.

Mourt's Relation: A Journal of the Pilgrims at Plymouth (1963), ed. Dwight B. Heath, Bedford, MA: Applewood Books. 
Newman, Robert D. (1988), 'Indians and Indian-Hating in Edgar Huntly and The Confidence Man', MELUS, 15.3: 65-74.

Rowe, John Carlos (2000), Literary Culture and U.S. Imperialism, Oxford: Oxford University Press.

Savoy, Eric (1998). 'The Face of the Tenant: A Theory of American Gothic', American Gothic New Interventions in a National Narrative, ed. Robert K Martin and Eric Savoy, Iowa City: University of Iowa Press, 3-19.

Sivils, Matthew Wynn (2001), 'Native American Sovereignty and Old Deb in Charles Brockden Brown's Edgar Huntly', American Transcendental Quarterly, 15.4: 293-304.

Slotkin, Richard (1973), Regeneration Through Violence, Middletown, CT: Wesleyan University Press.

Williams, Roger (1997), A Key Into the Language of America, Bedford, MA: Applewood Books.

Winthrop, John (1996). The Journal of John Winthrop, 1630-1649, ed. Richard S. Dunn, James Savage and Laetitia Yeandle, Cambridge, MA: Harvard University Press. 